\title{
St. Francis in Ecstasy (Bellini)
}

In the morning, the voices wake him.

A crack in the rock fixes the light.

He looks west with the egret and donkey.

A cluster of copper-green leaves

shakes above the fissure.

He forgets his sandals by the bed, his open book on the table.

\section{Alba}

If the morning could keep this frieze of rumpled sheets like fossil imprints in the lumpy bed, then I might also keep the hawk over the ravine, the flawed image in the mirror, the new wine.

Last night in the empty vineyards I looked west to the fast-moving clouds over Rocher des Vierges, and I wanted to hold that. And hold the silence-or almost silencebroken by a few barking dogs and the sound of the seedpods shaking on the plane tree.

Impossible to keep anything. Impossible to carry anything away, at least not what I want to take: fistfuls of flowering herbs, the wind from any of the six directions, love's progressif, that is, it's possible for love to progress, when it may be rooted like local honey in the domain with the stubborn vines, among the strong flavors of this world, rose garlic, aneth, black radishes - and you, this morning. 